Acta Regionalia et Environmentalica 1

Nitra, Slovaca Universitas Agriculturae Nitriae, 2018, pp. 15-21

\title{
POTENTIAL OF SHORT FOOD SUPPLY CHAINS, THEIR ROLE AND SUPPORT WITHIN THE RURAL DEVELOPMENT POLICY IN THE SLOVAK REPUBLIC
}

\author{
Norbert FLORIŠ*, Pavol SCHWARCZ \\ Slovak University of Agriculture in Nitra, Slovak Republic
}

\begin{abstract}
Current unfavourable situation in agricultural sector of the Slovak Republic makes national public authorities to look for possible solutions for satisfaction of local producers and consumers as well. Increase of domestic production in the programming period 2014-2020 with focus especially on producing high quality products is a challenge for Slovak government and local producers, too. In this paper we reveal the theoretical determination, legal limitations, opportunities for support and the level of implementation of short food supply chains as a tool for farmers, producers and processors to increase the added value of their products through promotion of existing and creation of new local markets. The possible support is described both in terms of the rural development policy as well as the regional policy, under limitations defined in European and national legal documents. The level of implementation of short food supply chains in agricultural sector of the SR is described in relation to the Rural Development Programme of the Slovak Republic 2014-2020.
\end{abstract}

Keywords: short food supply chain, rural development policy, farmer, rural development programme

Rural development provides Member States with financial resources which can be managed on national or regional level within multiannual programmes. The new regulation on rural development for the period of 2014-2020 concerns six economic, environmental and social priorities, while Member States within their programmes identify problems to be solved and define clear objectives to be achieved in compliance with relevant priorities, taking into account national conditions and specific features of each Member State.

The Slovak Republic is a rural country with predominantly mountainous character, with $60 \%$ of its territory covered with mountains and $40 \%$ with lowlands. $48 \%$ of territory of the country is covered with agricultural land. Slovak agricultural sector is represented by a significant share of small enterprises with the standard output of less than $15,000 €$ and by a smaller number of large enterprises with the standard output of more than $250,000 €$. The low added value to agricultural primary production mostly focused on production of cereals and oilseeds is the general character of agricultural production in Slovakia. Increasing export of agricultural primary production raw materials and import of final food products causes that only $65 \%$ of domestic production is processed in Slovakia, although Slovak agriculture and food industry can produce high quality products. Continuous reduction of number of employees in agriculture causes that in this indicator Slovakia reaches only half of the EU average. Land abandonment due to a very extensive agriculture is a very common phenomenon in some areas. The unemployment rate is $17 \%$ in rural areas; it is even $20 \%$ in some districts and villages - much more than the EU average (RDP, 2015).
As well as European public authorities and governments of Member States, the Slovak government realises problems in Slovak agriculture and the necessity to propose some effective solutions, which can be seen in reduction of costs connected to the sale and distribution through short food supply chains and in promotion of income of primary producers through the direct sale on farm - only $3 \%$ of agricultural production is sold directly, the objective is $7 \%$ until 2020 . Nowadays there are only five farmers' markets in Slovakia, the objective is fifteen until 2020. The importance of local and regional markets increases because it is a key aspect for food producers to keep and improve their positions at the domestic market. The quality of products is another aspect which must be considered. It is necessary to increase the share of domestic production with higher added value through better quality of products, innovations, regional and local specialties, etc. the objective is to process $80 \%$ of domestic production until 2020 (RDP, 2015).

Considering objectives defined it might seem that organising farmers in short food supply chains could be an appropriate solution for the identified problems. However, before we make such a simple conclusion, we should ask some specific questions: what has been done for achieving defined objectives? Are there tools defining rules and the way of support for farmers to achieve these objectives? Can farmers organized in short food supply chains achieve a higher added value than farmers doing the business individually? Can integration of farmers into short food supply chains bring social benefits in rural areas? And what in fact are the short food supply chains? 


\section{Theoretical background}

The development of food supply chains in recent years has brought a wide scale of terms and definitions within European and also global context. Considering the European context, it is necessary to recognise the two types of food supply chains - local food systems (LFS) and short food supply chains (SFSC). However, when studying theories on food supply chains, another term occurs, the so-called "alternative food networks" (AFN), which seems to be an umbrella term covering all the other types of food supply chains. To clarify this status, it is first necessary to explain what the term "alternative food networks" means.

There are several definitions for AFN. For example, AFN are "new and rapidly mainstreaming spaces in the food economy defined by - among other things - the explosion of organic, Fair Trade, and local, quality, and premium specialty foods" (Goodman et al., 2009). Initially, AFN products were sold through charity shops, food co-ops, farm markets, box schemes and community supported agriculture (CSA) schemes (Maye and Kirwan, 2010). The last three schemes are, however, classified within the local food systems (LFS) - the food supply chains limited by the geographic area and involving the whole life cycle of the food, i.e. from its production to the sale. Thus, it might seem that LFS are the subgroup of the AFN or at least they overlap through their characteristics. However, when we consider the fact that today AFN products are usually sold in supermarkets we come to the idea that AFN and LFS are two different schemes. Detailed observation of short food supply chains will show that these represent the further separated food supply chains with different characteristics and purpose.

Van der Ploeg (2000) defines new food supply chains as a "commonly recurring phenomenon in several fields of rural development centred on distinctive product qualities including organic farming, high quality production and region-specific products". Short food supply chains (SFSC) are based on their capacity to re-socialize or re-spatialize food, thereby allowing the consumer to make value-judgements about the relative desirability of foods based on their own knowledge, experience, or perceived imagery (Marsden et al., 2000). The SFSC concept is more specific than AFNs, and, rather, covers (the interrelations between) actors who are directly involved in the production, processing, distribution, and consumption of new food products (Renting, Marsden and Banks, 2003). As the term "short" indicates, there is a significant emphasis put on minimising the distance which the food has to overcome travelling from the producer to the consumer's table. Consumers do not need to travel long distances in order to purchase their desired favourite food from the farmer, food producer or processor. Instead of travelling to a remoted town and spending much time in a crowded supermarket, saving time and travel costs when shopping at the farm in the neighbourhood seems to be a great benefit of SFSC and environmental aspects (reduction of emissions) are considerable, too. The most highlighted is, however, the "development of trusting relationships between producers and consumers" (Kneafsey et al., 2013). The social aspect based on building relationship between the farmer/producer/processor and his/her customers and personal contact of both actors reinforced by mutual trust is a key characteristic of this relationship. A farmer is aware of his/her customer's importance for the business and the customer is aware of the quality of products - local, natural and healthy - provided by the farmer. If these characteristics are contained in the information and product embedded with this information, for example printed on the package or communicated in the face-to-face contact, reaches the customer, it allows him/her to make the association with the place of production (Marsden et al., 2000).

There are three main types of SFSC identified - face-toface, spatial proximity and spatial extended. Marsden et al. (2000) provides their following characteristics:

1. Face-to-face - consumer purchases a product directly from the producer/processor on a face-to-face basis. Authenticity and trust are mediated through personal interaction. The Internet now also presents opportunities for a variant of face-to-face contact through on-line trading and web pages.

2. Spatial proximity - products are produced and retailed in the specific region (or place) of production, and consumers are made aware of the 'local' nature of the product at the point of retail.

3. Spatially extended - where value and meaning laden information about the place of production and those producing the food is translated to consumers who are outside of the region of production itself and who may have no personal experience of that region.

Starting from these definitions we can state that the distance (or radius) between the producer and the consumer or, in a broader perspective, the distance between the place of production (or sale) and the consumer's residence, is one of the indicators determining whether the supply chain where the product is made and provided, can be considered as "short". The product is thus bound to a specific geographic area. Because SFSC often involve intermediaries acting between farmers/producers/processors and consumers, number of intermediaries is a second indicator which is considered when identifying SFSC.

Despite concrete definitions of SFSC within large available literature it is necessary to define their qualitative and quantitative limitations. These limitations are important when identifying SFSC for the purpose of receiving support from national or European support schemes. Therefore, such limitations must be defined by official legal documents on European and national level.

\section{Legal base}

Legislation represents the basic tool for public authorities to define qualitative and quantitative characters of SFSC. Such explanation is, of course, too general and it does not render exactly the character of rules dedicated to rural actors carrying out activities within SFSC. To be more precise, such legal documents must first clearly determine basic terms - short supply chains and local markets. To allow the demarcation between these two, the quantitative limitations should be defined, taking into account specific geographic features of the area concerned. Last but not least, it is necessary to define the qualitative aspects, especially concerning the hygiene rules and obligations of producers. 
Two European legal documents determine limitations of short food supply chains. The Commission Delegated Regulation (EU) No. 807/2014 and the Regulation (EU) No. 1305/2013 represent the basic European legislation determining SFSC from the point of view of distance and number of intermediaries. In accordance with the Article 11 of the Commission Delegated Regulation (EU) No. 807/2014:

- support for the establishment and development of short supply chains, as referred to in Article 35(2)(d) of Regulation (EU) No. 1305/2013 shall cover only supply chains involving no more than one intermediary between farmer and consumer;

- support for the establishment and development of local markets, as referred to in Article 35(2)(d) of Regulation (EU) No. 1305/2013 shall cover markets for which the rural development programme sets out a kilometric radius from the farm of origin of the product, within which the activities of processing and sale to the final consumer have to take place.

The Rural Development Programme of the Slovak Republic 2014-2020 (RDP) sets out the $100 \mathrm{~km}$ radius for local market from the place of origin of product or within the territory of a Higher Territorial Unit where the enterprise resides.

Concerning some complementary regulations, the Council Regulation (EC) No. 834/2007 lays down legal framework for all levels of production, distribution, control and labelling of organic products which may be offered and traded in the EU. The Commission Regulation (EC) No. 889/2008 lays down rules for implementation of the Regulation No. 834/2007. Requirements for SFSC determined within European legal documents are binding for farmers/ producers/processors in each EU Member State. Concerning the national level, both the "distance" and "intermediary" criteria determined within the Commission Delegated Regulation (EU) No. 807/2014 have been implemented into the Rural Development Programme of the Slovak Republic 2014-2020. Other national legal documents set the rules concerning the direct sale of food to consumers and requirements for food establishments and small volumes, namely:

- the Slovak Government Regulation No. 360/2011 Coll. Laying down hygienic requirements for direct sale and supply of primary products of plant and animal origin small volumes and for supply of the milk and milk products to final consumer and other retail establishments;

- the Slovak Government Regulation No. 100/2016 Coll. Amending and supplementing the Slovak Government Regulation No. 360/2011 Coll.;

- the Slovak Government Regulation No. 359/2011 Coll. Laying down requirements on some food establishments and on small volumes.

The Regulation No. 360/2011 Coll. lays down hygienic requirements for direct sale and supply of small volumes of primary products to the final consumer or to local retails and determines obligations of such retail establishment operators. It also determines requirements for supply of milk and milk products from one retail establishment to the others, considering this supplying to be marginal, local and limited activity. Concerning small volumes of primary products, these involve fish, raw milk, eggs and bee honey, cereals, buckwheat, sorghum, millet, amaranth, legumes, oilseeds, potatoes, vegetables, fruit, herbs and cultivated mushrooms. They must come from a separately registered own production, harvest or breed. Procession and packaging of these products must not significantly change their character and cause their contamination. They can be only sold at a farm or at a local market. The term "local retail establishment" has been identified for supply of small volumes of primary products. Local retail establishment represents a small shop, appropriately equipped market place or a facility for common catering. Facilities such as supermarkets, distribution centres, wholesale facilities, and activities such as the doorstep selling, mail order selling, Internet selling or intermediary selling are excluded. Requirements determined in the Regulation No. 359/2011 Coll. concern the rules for production of meat. For better orientation of farmers, the Ministry of Agriculture and Rural Development of the Slovak Republic published the methodological handbook for application of the mentioned regulations in practice.

The three mentioned national regulations modify rules of directly applicable EU legal documents (Regulation (EC) No. 852/2004 of the European Parliament and of the Council of 29 April 2004 on the hygiene of foodstuffs and Regulation (EC) No. 853/2004 of the European Parliament and of the Council of 29 April 2004 laying down specific hygiene rules for food of animal origin) modification of which has been entrusted to internal law of individual Member States, only respecting hygiene requirements. Other relevant legal documents defining requirements for animal health, protection of animals, identification of animals, control of residues, zoonosis, food labelling, general food law, animal by - products, etc. are not concerned. However, farmers are obliged to follow these requirements regardless of whether they act within the SFSCs or not.

\section{Data and methods}

The data used in paper have been collected from the following resources:

- EUROSTAT database for the time period 2005, 2007, 2010 and 2013. The 2 indicators have been considered - the area of agricultural holdings and the standard output of agricultural holdings;

- Agricultural Paying Agency (Annual Report on the Rural Development Programme of the SR 2014 - 2020) for the time period 2015 and 2016. The following indicators within the sub-measure 4.2 - Support for investments for processing/placing on the market and/or developing agricultural products have been considered: number of submitted projects, total requested grant, number of approved projects, total approved grant and the share of budget contracted.

We focus on the potential of the short food supply chains development through level of concentration of small and medium enterprises in the primary production sector into the short food supply chains. Subsequently, the efficiency of the Rural Development Programme of the SR 2014-2020 measures will be evaluated. 


\section{Results and discussion}

In the first part we focus on analysis of indicators representing the trend in development of small and medium enterprises within the observed time period. The development of small and medium enterprises had negative tendencies especially in case of agricultural enterprises with the area of less than 2 hectares (Figure 1). While in 2005 these enterprises represented almost $50 \%$ of area of all agricultural holdings, it was only $37 \%$ in 2007, 36\% in 2010 and 34\% in 2013. The situation of holdings with 2-4.9 hectares is much more stable at the level of approximately $26 \%$ of the total number of agricultural holdings. Concerning holdings with the area of more than 5 hectares, we have registered growing tendencies in number of these holdings from $24 \%$ in 2005 up to $40 \%$ of the total number of agricultural holdings in 2013. However, this growth has been at the expense

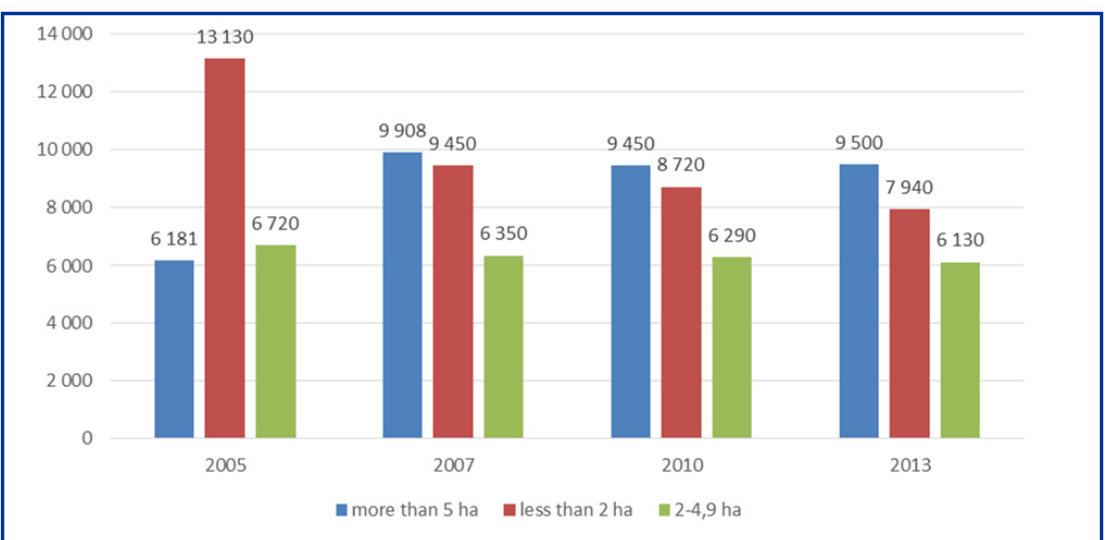

Figure 1 Number of agricultural holdings according to the area Source: Eurostat

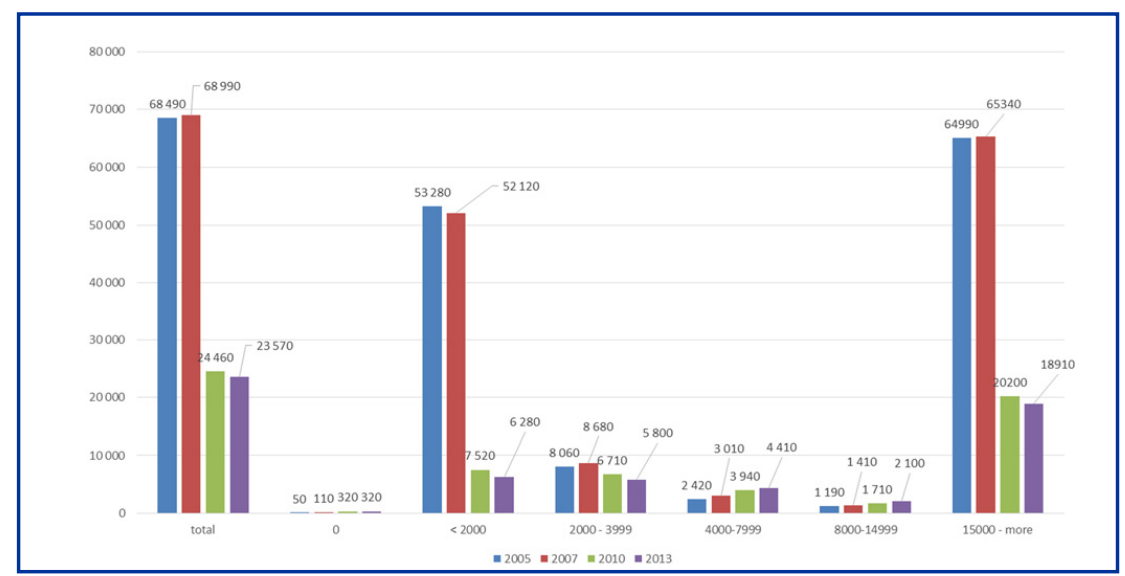

Figure 2 No. of agricultural holdings according to the standard output Source: Eurostat less than 2 hectares number of which declines, as they are less profitable and often absorbed by larger farms. This fact shows how vulnerable these holdings are in comparison with larger farms.

The figure 2 indicates the numbers of agricultural holdings in connection to their overall economic size through the standard output. There are significant differences between observed time periods considering especially agricultural holdings with the standard output less or equal to 2,000 $€$. While in 2005 these holdings represented almost $78 \%$ of total number of agricultural holdings, it was $76 \%$ in $2007,31 \%$ in 2010 and $27 \%$ in 2013. On the other hand, growing tendencies of holdings with the standard output 2,000-3,999 € are considerable, too, as they represented $12 \%$ of total number of agricultural holdings in 2005, while it was $13 \%$ in 2007, 27\% in 2010 and 25\% in 2013. of smaller holdings with the area of

\section{.}

\section{.} a set of in some a set of regional programmes or both a national programme and a set of regional programmes. Each programme identifies a strategy for meeting targets in relation to the Union priorities for rural development and a selection of measures and includes thematic sub-programmes to address specific needs in areas of particular importance to them. Thematic subprogrammes concern, among others, young farmers, small farms, mountain areas, women in rural areas, climate change mitigation and adaptation, biodiversity and the creation of short supply chains.

On European level, support of short food supply chains has been indicated by the European Commission in its Report to the European Parliament and the Council on the case for a local farming and direct sales labelling scheme. On national level, the support has been indicated by the Ministry of Agriculture and Rural Development of the SR in its Concept of Agricultural Development of the SR 2013-2020. Specific rules for support of short food supply chains are defined in the Rural Development Programme of the Slovak Republic 2014-2020 (RDP). In terms of the main priority 3 Promoting Food Chain Organisation, 
Including Processing and Marketing of Agricultural Products, Animal Welfare and Risk Management in Agriculture, the RDP defines conditions for support of actors within SFSC, addressing focus areas $3 \mathrm{~A}$ - improving competitiveness of primary producers by better integrating them into the agri-food chain through quality schemes, adding value to agricultural products, promotion in local markets and short supply circuits, producer groups and organisations and inter-branch organisations, 6A - facilitating diversification, creation and development of small enterprises, as well as job creation and $6 \mathrm{~B}$ - fostering local development in rural areas. The purpose of the synergy created among selected focus areas is to contribute to the increase of the added value creation in agricultural production, improvement of cooperation between farmers and between farmers and other actors within the food supply chain and, finally, contribution to development of SFSC. The support especially concerns investments into properties in terms of selling and processing agricultural products, starting the production of new and traditional products, introduction of new technique / technologies, and creation of small places for selling agricultural products. The support is provided within the Measure 4 - Productive investments, sub-measure 4.2 - Support for investments for processing/placing on the market and/or developing agricultural products, and is eligible for farmers and producers/processors of agricultural and food products, with the following eligible activities:

- construction, reconstruction and modernisation of objects for processing, storage, marketing and / or development of agricultural and food products;

- acquisition, reconstruction and modernisation of facilities, machines, apparatuses and technologies, processing and production capacities including laboratory equipment within the process of processing, storage, marketing and / or development of agricultural and food products, including products with protected designation of origin and the protected geographical indication and including traditional specialities guaranteed;

- investments into constructions or technologies for creation or modernisation of local collecting network receiving, storage, adjustment, sorting and packaging;

- purchase of cold or refrigerated trucks or cars, trailers or semitrailers, transport trucks;

- introduction of technologies and procedures for creation of new or better quality products and opening new markets especially in connection with the SFSC;

- investments into construction or technologies for better use or elimination of by - products or waste;

- investments for creation and equipment of own company shops and for improvement of work environment of employees.

Assessing the level of implementation of short food supply chains projects, we used data provided by the Agricultural Paying Agency in its summary report up to 31. 12. 2016. There were 412 projects approved in terms of the sub-measure 4.2 in 2016 and the total approved grant was $166,486,768 €$. This represents $83 \%$ of limits for public expenditures (EU + SR) for the whole period of 2014-2020 determined for the sub-measure 4.2. When we consider the fact that only 46 projects were approved in 2015 (these were projects continuing in terms of the RDP 2007-2013), we can say that the progress in implementation of the sub-measure 4.2 was significant in 2016. The following tables and figures provide an overview in terms of providing support for short food supply chains in 2016 within the sub-measure 4.2 - Support for investments for processing/placing on the market and/or developing agricultural products in Slovakia as whole and in individual regions.

Distribution of support for the sub-measure 4.2 is expressed in table 2 and in figures 3 and 4 . There were 87 projects approved for the Nitra Region - this represents $21 \%$ of the total number of projects approved in Slovakia,

Table 1 Summary report on implementation of the sub-measure 4.2

\begin{tabular}{|c|c|c|c|c|}
\hline $\begin{array}{c}\text { Number of submitted } \\
\text { projects }\end{array}$ & $\begin{array}{c}\text { Total requested grant } \\
(€)\end{array}$ & $\begin{array}{c}\text { Number of approved } \\
\text { projects }\end{array}$ & $\begin{array}{c}\text { Total approved grant } \\
(€)\end{array}$ & $\begin{array}{c}\text { \% of budget } \\
\text { contracted }\end{array}$ \\
\hline \hline 618 & 285769047 & 412 & 166486768 & 83 \\
\hline
\end{tabular}

Source: Agricultural Paying Agency

Table 2 Summary report on implementation of the sub-measure 4.2 by regions of the SR

\begin{tabular}{|l||c|c|}
\hline \multicolumn{1}{|l||}{ Region of the SR } & Number of approved projects & Approved grant (€) \\
\hline \hline Bratislava (BA) & 11 & 2338096 \\
\hline Banska Bystrica (BB) & 66 & 34777531 \\
\hline Kosice (KE) & 42 & 16101456 \\
\hline Nitra (NR) & 87 & 39294963 \\
\hline Presov (PO) & 61 & 29952083 \\
\hline Trencin (TN) & 48 & 14097176 \\
\hline Trnava (TT) & 57 & 20490804 \\
\hline Zilina (ZA) & 40 & 9434658 \\
\hline
\end{tabular}

Source: Agricultural Paying Agency 


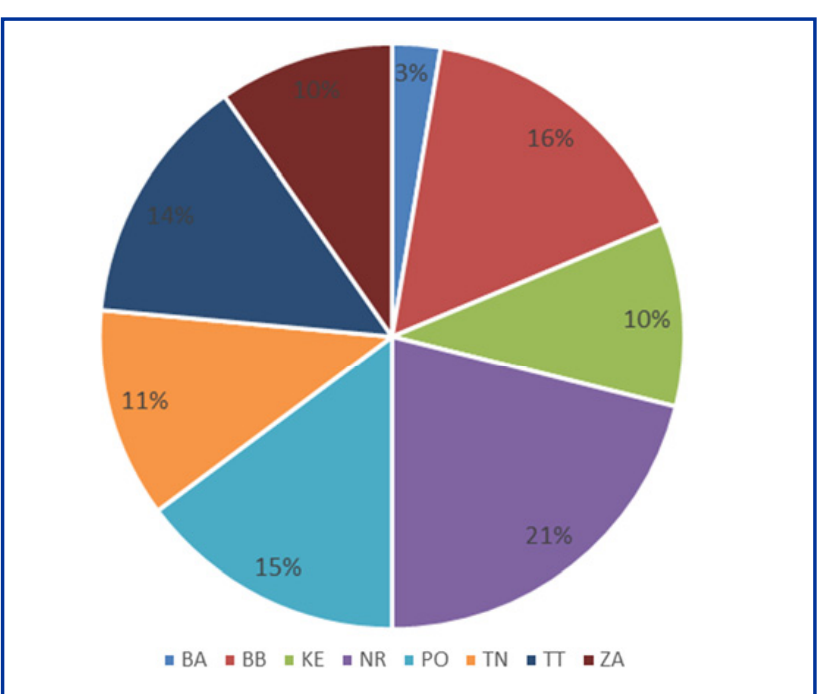

Figure 3 Summary report on implementation of the submeasure 4.2 by regions of the SR - approved projects

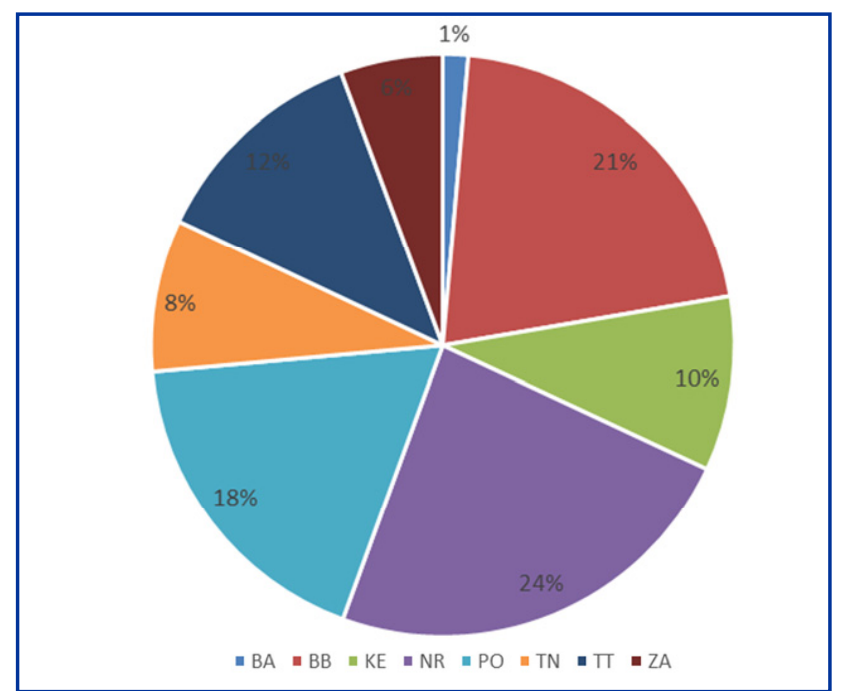

Figure 3 Summary report on implementation of the submeasure 4.2 by regions of the SR - approved grants

the highest share of projects approved for the sub-measure 4.2 in 2016. Concerning the approved grant within the mentioned sub-measure, the Nitra Region keeps the $1^{\text {st }}$ place with $39,294,963 €$. This represents $24 \%$ of the total grant approved in Slovakia for the sub-measure 4.2 in 2016.

Horizontal and vertical cooperation of farms organised in SFSC, cooperation between SFSC actors when creating logistic platforms for promotion of SFSC and local markets, and dissemination activities can be supported, too. The support is eligible for farmers and producers / processors of agricultural and food products. Specifically, the following activities are eligible:

- studies or plans concerning the relevant area, feasibility studies, creation of business plans or other local development strategies;

- recovery of the relevant logistic platform, resp. the SFSC or local market with objective to ensure the project feasibility;
- relevant samples, measurements and tests for realisation of business plans, studies, surveys or cooperation.

In the programming period 2014-2020 the European Commission provides an option to use financial resources from other EU funds through the Community-led local development (CLLD). This principle includes the European Agricultural Fund for Rural Development (EAFRD) and the European Regional Development Fund (ERDF) and complementarity of both funds is ensured by different eligibility of applicants and activities. Support from the ERDF is provided by the Integrated Regional Operational Programme 2014-2020 (IROP). Conditions for providing the support are defined in the Priority axis 5 - Community-led Local Development and similarly to the RDP, IROP is oriented on the local context of labour market, with focus on sustainable jobs development and growth. The difference between both programmes is in the fact that IROP provides the support regardless the sector, except for support of investments in agricultural primary production which is the subject of support from the RDP. On the one hand, IROP supports creation of new or promotion of existing micro and small enterprises, self - employed persons and cooperatives through promotion of local food supply chains, networking on the level of local economy and exchange of experiences. On the other hand, the support is also of infrastructural character, as creation and reconstruction of municipal market places to support local producers are eligible activities, too. The support is provided to Local Action Groups (LAGs), municipalities and their associations, microregions, civic associations, and not for profit organisations, church organisations and self - employed persons, micro and small enterprises except for those eligible to receive the support from the RDP.

\section{Conclusion - final statements and future challenges}

In the RDP there are $400,390,000 €$ planned for the priority 3 - Promoting Food Chain Organisation, Including Processing and Marketing of Agricultural Products, Animal Welfare and Risk Management in Agriculture. This amount represents $19.25 \%$ of total financial resources planned for the RDP, the $2^{\text {nd }}$ highest amount right after the priority 4 Restoring, Preserving and Enhancing Ecosystems Related to Agriculture and Forestry. 200,000,000 $€$ is planned for public expenditures within the sub-measure 4.2 - Support for investments for processing/placing on the market and/ or developing agricultural products. This huge financial support, together with eligible activities in terms of the RDP measures and with qualitative and quantitative rules clearly stated in legal documents and explained in methodological guidelines should provide an answer to our questions we have asked at the beginning - what has been done for achieving defined objectives? Are there some tools defining rules and the way of support for farmers to achieve these objectives? The answer is - yes. Public authorities have correctly identified that in terms of agricultural production the support for small farmers and producers / processors is a key aspect for increasing the domestic production, while added value of agricultural products through the improvement of their quality is a basic step towards 
increasing their sales. To achieve these challenges, farmers are encouraged to join and cooperate in short food supply chains and when we consider the figures concerning the sub-measure 4.2 in 2016, we can say that the progress in these challenges achievement is significant. Nothing is left to chance - additionally to the RDP, municipalities, associations and local action groups have the chance to get financial resources from the IROP to improve the local infrastructure and thus support local producers.

The added value of agricultural products is one of the key elements on which the whole strategy of short food supply chains promotion is built. This fact brings us to the resting two questions asked at the beginning: Can farmers organized in short food supply chains achieve a higher added value than farmers doing the business individually? Can integration of farmers into short food supply chains bring social benefits in rural areas? Because increase of added value is one of the main objectives and activities for its achieving are the subject of financial support, we should logically suppose that it should. It is expected that investments into the infrastructure, facilities, and devices will allow farmers to produce high quality products and through their participation in the short food supply chain they will achieve higher sales of their products and improve their social situation.

\section{References}

COMMISSION Delegated Regulation (EU) No. 807/2014 of 11 March 2014 supplementing Regulation (EU) No. 1305/2013 of the European Parliament and of the Council on support for rural development by the European Agricultural Fund for Rural Development (EAFRD) and introducing transitional provisions. COMMISSION Regulation (EC) No. 889/2008 of 5 September 2008 laying down detailed rules for the implementation of Council Regulation (EC) No. 834/2007 on organic production and labelling of organic products with regard to organic production, labelling and control.

COUNCIL Regulation (EC) No. 834/2007 of 28 June 2007 on organic production and labelling of organic products and repealing Regulation (EEC) No. 2092/91.

EUROSTAT. http://appsso.eurostat.ec.europa.eu/nui/show. do?dataset=ef_m_farmleg\&lang=en

GOODMAN, D. - GOODMAN, M. K. 2009. Alternative Food Networks. 2009.

INTEGRATED Regional Operational Programme 2014-2020.

KNEAFSEY, M. et al. 2013. Short Food Supply Chains and Local Food Systems in the EU. A State of Play of their Socio-Economic Characteristics. In JRC Scientific and Policy Reports, 2013.
MARSDEN, T. et al. 2000. Food Supply Chain Approaches: Exploring their Role in Rural Development. In Sociologia Ruralis, vol. 40, 2000, no. 4, p. 424-438.

MAYE, D. - KIRWAN, J. 2010. Alternative Food Networks. In Sociopedia.isa, 2010.

MINISTRY of Agriculture and Rural Development of the Slovak Republic. 2013. Concept of Agricultural Development of the SR 2013-2020.

MINISTRY of Agriculture and Rural Development of the Slovak Republic, State Veterinary and Food Administration of the Slovak Republic, 2011. Handbook for application of Slovak Republic Government Regulations laying down requirements on some food establishments and on small volumes. ISBN 978-80-7148-062-4.

REGULATION (EC) No. 852/2004 of the European Parliament and of the Council of 29 April 2004 on the hygiene of foodstuffs.

REGULATION (EC) No. 853/2004 of the European Parliament and of the Council of 29 April 2004 laying down specific hygiene rules for food of animal origin.

REGULATION (EU) No. 1305/2013 of the European Parliament and of the Council of 17 December 2013 on support for rural development by the European Agricultural Fund for Rural Development (EAFRD) and repealing Council Regulation (EC) No. 1698/2005.

RENTING, H. - MARSDEN, T.K. - BANKS, J. 2003. Understanding Alternative Food Networks: Exploring the role of Short Food Supply Chains in Rural Development. In Environment and Planning A, vol. 35, 2003, pp. 393-411.

REPORT from the Commission to the European Parliament and the Council on the case for a local farming and direct sales labelling scheme. European Commission. 2013.

RURAL Development Programme of the Slovak Republic 2014-2020.

SLOVAK Government Regulation No. 100/2016 Coll. Amending and supplementing Slovak Government Regulation No. 360/2011 Coll.

SLOVAK Government Regulation No. 359/2011 Coll. Laying down requirements on some food establishments and on small volumes. SLOVAK Government Regulation No. 360/2011 Coll. Laying down hygienic requirements for direct sale and supply of primary products of plant and animal origin small volumes and for supply of the milk and milk products to final consumer and other retail establishments.

SUMMARY report on implementation of the RDP 2014-2020 up to 31.12.2016. Agricultural Paying Agency. Available at http://www. apa.sk/download/11068

van DER PLOEG, J.D. et al. 2000. Rural Development: From Practices and Policies towards Theory. In Sociologia Ruralis, vol. 40, 2000, no. 4, p. 391-408. 